\title{
KOMERSIALISASI BANTEN DALAM WACANA PENGUATAN IDENTITAS KEHINDUAN SEBAGAI IMPLEMENTASI AJARAN BHAKTI MARGA DI BALI
}

\author{
Oleh: \\ A.A KADE SRI YUDARI \\ Pascasarjana Universitas Hindu Indonesia \\ Denpasar \\ sriyudari15@gmail.com
}

\begin{abstract}
The presence of "banten" in the Hindu tradition in Bali has been going through a long history. In the book of Yajur Veda, there is an offering offered to the Deity who is the manifestion of Brahman in the form of; gandam, ksatam, puspam, dupam, dipam, toyam, gretam, and soma. Whereas, in the Tantric teachings which are still very influential in Bali it is stated that to show devotion to God one should carry out the concept of Panca Tattwa namely; matsya, mamsa, madhya, mudra, and maithuna. Both the Vedic teachings and the Tantrayana, and the local mind of Balinese people always underlie the offering of "banten" which is packaged in the symbols of human hope for God's manifestation. The occurrence of the multidimensional crisis today results in the "banten" being commercialized, but does not affect the mindset of the Hindu community in Bali in carrying out the dharma bhakti to God. In fact, the community has become stronger and stronger to hold the belief in showing their identity of desire.
\end{abstract}

Keywords: Commercialization of Banten, Strengthening Identity, Bhakti Marga

\begin{abstract}
Abstrak
Hadirnya "banten" dalam tradisi Hindu di Bali melewati perjalanan sejarah yang panjang. Di dalam kitab Yajur Weda disebutkan, adanya persembahan yang dihaturkan kepada Dewa sebagai manifestasi dari Brahman berupa; gandam, ksatam, puspam, dupam, dipam, toyam, gretam, dan soma. Sedangkan, di dalam ajaran Tantrayana yang masih sangat berpengaruh di Bali disebutkan bahwa untuk menunjukkan rasa bhakti kepada Tuhan hendaknya menjalankan konsep Panca Tattwa yakni; matsya, mamsa, madhya, mudra, dan maithuna. Baik ajaran Weda maupun Tantrayana, dan alam pikiran lokal masyarakat Bali senantiasa melandasi adanya persembahan berupa"banten"yang dikemas dalam simbol-simbol pengharapan manusia terhadap manifestasi Tuhan. Terjadinya krisis multidimensial dewasa ini, berakibat "banten" dikomersialkan, akan tetapi tidak berpengaruh terhadap pola pikir masyarakat Hindu di Bali dalam menjalankan dharma bhakti kepada-Nya. Justru masyarakat memiliki keyakinan semakin ajeg dan kuat dalam menunjukkan identitas kehinduannya.
\end{abstract}

Kata kunci: Komersialisai Banten, Penguatan Identitas, Bhakti Marga 


\section{PENDAHULUAN}

Ajaran agama Hindu meliputi hal-hal yang sangat kompleks baik lahir maupun batin, akan tetapi dapat dilaksanakan secara individual maupun kolektif. Sifat ajarannya yang luwes dinyatakan dengan konsep; desa, kala, dan patra (menurut tempat, waktu, dan keadaan). Sedangkan sifat fleksibel memberikan peluang dalam pelaksanaannya menyesuaikan diri dengan kemajuan teknologi ilmu pengetahuan dan zaman serta situasi perekonomian. Adanya sifat luwes dan fleksibel dikarenakan Weda sebagai sumber ajaran Hindu bersifat mengatasi ruang dan waktu.

Tiga aspek yang menjadi kerangka agama Hindu meliputi; Tattwa, Susila, Ritual (upacara/ upakara). Tattwa membentuk pola pikir manusia tentang pemahaman sifat Weda; Susila, menggerakkan dan mengendalikan perilaku berdasar Tattwa; sedangkan Ritual (upacara/ upakara) untuk menguatkan keyakinan terhadap Tattwa. Ketiga aspek itu harus menyatu dan saling berkaitan, sehingga bila salah satu lemah atau tidak ada, maka kehidupan beragama tidak berjalan sempurna. Penonjolan salah satu aspek dari tiga kerangka tersebutmencerminkan dua hal pokok yakni kemampuan intelegensia dan "marga" yang digunakan dalam meniti kehidupan spiritual.

Dari ketiga aspek kerangka agama Hindu tersebut di Bali, aspek ritual (upacara/upakara) yang paling menonjol. Sehingga jalan atau' marga' untuk menuju/menghadap dan mendekatkan diri dengan Tuhan adalah melalui bhakti marga. Meskipun demikian, Weda sangat fleksibel dalam menyikapinya dengan menyediakan alternatif yang paling sesuai di mana hakikat keempat 'marga' dapat digunakan secara serentak dengan perimbangan bobot menurut kemampuan masing-masing. Inilah salah satu kebesaran agama Hindu sebagaimana disebutkan dalam Bhagawadgita IV.11 sebagai berikut.

"Ye yatha mam prapadyante, tams tathai va bhajamy aham, mama vartma nuvartante, manusyah partha savasah". Artinya: Dengan jalan bagaimanapun orang-orang mendekat, dengan jalan yang sama itu pula Aku memenuhi keinginan mereka, melalui banyak jalan manusia mengikuti-Ku O Partha.

Aspek ritual (upacara/upakara) sangat berkaitan dengan Panca Yadnya. Dalam Manawa Dharmasastra III.73 disebutkan sebagai berikut. "Ahuta, Huta, Prahuta, Brahmahuta, dan Prasita". Artinya: yadnya adalah bhakti dalam bentuk pengorbanan suci yang tulus ikhlas.

Oleh karena itulah yadnya diadakan, dengan berpedoman bahwa hidup manusia berawal dari adanya Rna atau " hutang" kepada tiga pihak yakni; Dewa, Pitara dan Rsi. Ketiga "hutang" itulah yang dibayar dengan cara melakukan ritual (upacara/upakara). Sedangkan ritual yang diadakan selalu disertai dengan upakara yang disebut "banten". Banten semula diperkenalkan oleh Maharsi Markandeya sekitar abad ke-8 kepada penduduk di sekitar pertapaan beliau di Desa Puakan-Taro (TegallalangGianyar). Banten kemudian dikembangkan kepada umat Hindu yang tidak menguasai mantra-mantra dalam kegiatan bhaktinya. Kata 'banten' disamakan dengan kata 'bali', sehingga orang yang melakukan upacara persembahyangan menggunakan 'banten' dikatakan sebagai orang Bali.

Dahulu, ketika kehidupan masyarakat Bali sepenuhnya agraris, banten menjadi cerminan utuh keikhlasan manusia Bali. Segala isi banten diambil dari kebun atau sawah sendiri dan dikerjakan dari cucuran keringat sendiri. Hanya sebagian kecil yang dibeli terutama bahan yang tidak tersedia di kebun atau sawahnya. Namun kini ketika sektor Pariwisata berkembang pesat sudah semakin jarang terdengar bahan baku 'banten' diambil dari hasil kebun dan sawah. Bahkan sudah umum bagi orang Bali saat ini, 'banten' dibeli dari pasar atau tukang banten. Mereka yang melaksanakan upacara tinggal mengeluarkan uang yang cukup, banten apa pun bisa di dapat siap pakai di tempat. Inilah fakta yang terjadi seiring dengan kemajuan teknologi dan ilmu pengetahuan, uang menjadi tolak ukur segalanya. Walau 'banten' sudah menjadi barang konsumtif dan kebutuhan mutlak dalam kehidupan sehari-hari, akan tetapi masyarakat tetap semangat melaksanakan berbagai ritual. Dari latar belakang di atas muncul pertanyaan mengapa masyarakat Hindu di Bali tidak dapat dipisahkan dengan adanya berbagai jenis banten walau krisis melanda, sehingga menyebabkan banten dikomersialkan? 


\section{PEMBAHASAN}

\section{1. "Banten" Sebagai Identitas Kehinduan}

Dalam lontar Markandeya Tattwa disebutkan bahwa kedatangan Rsi Markandeya pertama kali di Bali sekitar abad ke-8 tahun Saka 858 dengan pengikut berjumlah \pm 400 orang. Maha Rsi bersama pengikutnya berkenan membuka daerah baru di Puakan Taro-Tegallalang (kabupaten Gianyar) saat ini. Namun kedatangan beliau disambut oleh bencana sampai akhirnya banyak pengikut yang meninggal dunia. Akhirnya beliau kembali ke Gunung Raung bersemadhi mencari petunjuk tentang penyebab semua kejadian. Setelah mendapat wahyu Tuhan Yang Maha Kuasa bahwa kondisi tanah Bali tidak sama seperti daerah lain sehingga harus melakukan 'pangruwatan' terlebih dahulu ketika pertama kali memasukinya.

Sejak saat itu beliau dengan rombongan yang lebih banyak (dua kali lipat) memutuskan untuk kembali ke Bali. Beliau mengajarkan cara membuat berbagai bentuk upakara sebagai sarana upacara, mula-mula terbatas kepada para pengikutnya, lama-kelamaan berkembang pada penduduk di sekitar Desa Taro. Untuk memulihkan keadaan demi keselamatan beliau serta pengikutnya maka beliau menyarankan dan melakukan hal-hal sebagai berikut: (a) melaksanakan ritual upacara 'mendem pedagingan Panca Datu' sesuai petunjuk menggunakan sarana 'sesajen'di Pura Besakih. (b) setiap memasuki daerah baru atau tempat baru untuk keselamatan masyarakat disarankan melaksanakan ritual upacara pembersihan tanah yang akan ditempati.

Demikianlah dari tahun ke tahun ajaran serta petunjuk beliau ditaati dan terus dilaksanakan sampai saat ini oleh masyarakat yang beragama Hindu. Pentingnya melaksanakan suatu upacara tentu sesuai dengan yang digariskan dalam kerangka agama Hindu yakni; Tattwa, Susila, dan Ritual (upacara) Mas Putra, 1974). Sarana upacara adalah upakara yang dipopulerkan dengan istilah 'Banten' di Bali sedangkan 'Wedya' di India. Istilah 'Wedya' juga disebutkan dalam beberapa pustaka agama Hindu yang artinya banten. Kata 'upakara' terdiri atas dua kata yaitu 'upa' yang artinya sekeliling atau sesuatu yang berhubungan dengan; dan 'kara' artinya tangan. Sehingga upakara berarti segala sesuatu yang dibuat oleh tangan atau sarana persembahan yang berasal dari jerih payah bekerja.

Banten juga sering disebut Wali. Kata 'wali' artinya wakil (Kamus-BB) yang juga mengandung pengertian kembali. Wali yang berarti wakil mengandung makna simbolis bahwa banten merupakan wakil dari isi alam semesta ciptaan Tuhan. Sedangkan wali yang artinya kembali bermakna bahwa segala yang ada di alam semesta ciptaan Tuhan dipersembahkan kembali oleh manusia kepadaNya sebagai pernyataan rasa terima kasih. Kata 'wali' sering dikatakan 'bali' dimana antara konsonan /w/ dengan konsonan /b/ terjadi persengauan bunyi yang hanya dibutuhkan pada awal bentuk dasarnya.

Banten memiliki jenis, bentuk dan bahan yang bermacam-macam. Secara sepintas memang terlihat unik dan rumit, namun apabila diteliti secara mendalam dapat dipahami bahwa keunikan dan kerumitannya mengandung makna simbolik yang sangat dalam terpadu dengan daya estetika yang tinggi dan mengagumkan. Unsur estetika dalam banten menjadi penting karena dapat menuntun pikiran dengan penuh rasa kebahagiaan pada saat memuja Tuhan. Dalam lontar 'Yadnya Prakerti; dan lontar 'Kusuma Dewa', banten yang bahannya bermacam-macam itu pada prinsifnya terdiri dari unsur isi alam sebagai berikut:

a) Mataya, adalah bahan banten yang berasal dari sesuatu yang tumbuh atau tumbuh-tumbuhan seperti; daun, bunga, buah dan sebagainya.

b) Maharya, bahan yang berasal dari sesuatu yang lahir, diwakili oleh binatangbinatang tertentu seperti kerbau, kambing, sapi, dan sebagainya.

c) Mantiga, adalah bahan banten yang berasal dari telor seperti telor ayam, itik, angsa, dan sebagainya.

d) Logam atau datu seperti perak, tembaga, besi, emas, timah (panca datu).

e) Air atau cairan; ada lima macam cairan yang digunakan untuk banten yaitu; 1) air yang berasal dari jasad atau sarira diwakili 'empehan' atau susu; 2) air yang berasal dari buah-buahan diwakili berem; 3) air yang berasal dari uap atau kukus diwakili arak; 4) air yang berasal dari sari bunga diwakili madu; 5) air air yang berasal dari tanah atau bumi 
diwakili air hening (jernih). Kelima zat cair ini disebut Panca Amerta.

f) Api dalam wujud dupa dan dipa.

g) Angin dalam wujud asap yang harum.

Ketujuh bahan itulah yang menjadi unsur pokok banten dan dipersembahkan kembali kepada Sang Pencipta. Dalam melakukan ritual atau ber-yadnya, tiga hal harus seimbang yaitu; upacara, upakara, dan puja mantra yang digunakan pemandu ritual (Singer, 2014). Di samping itu perlu kemanunggalan tri manggala yadnya yakni; orang yang beryadnya, wiku tapini atau tukang banten, dan yang muput yadnya.

Upakara berupa banten dan sarana pendukungnya adalah simbol atau niyasa yang berfungsi sebagai; kekuatan Tuhan, wujud bhakti, prasadam/lungsuran/surudan, sarana penyucian roh dan sebagai pengganti mantra. Dengan demikian tujuan awal banten dibuat dan dikembangkan kepada umat Hindu yang tidak menguasai mantra dalam kegiatan bhaktinya. Dan kini tradisi yang diwariskan oleh Rsi Markandeya berkembang secara turuntemurun pada masyarakat yang beragama Hindu di manapun berada sesuai situasi dan kondisi masing-masing. Oleh karena itu, 'banten' selain sebagai sarana upacara juga merupakan ciri penguat identitas kehinduan demi ajeg dan lestarinya tradisi warisan para leluhur.

\section{2. "Banten" dan Ajaran Bhakti Marga}

Menurut Ninian Smart (dalam Agung Paramita, 2018: 40) ada tujuh dimensi setiap agama. Salah satu dimensi yang penting adalah dimensi praktis-ritual. Dalam aktivitas beragama umat Hindu di Bali dimensi praktis ritual ini tercermin melalui banten. Tradisi beragama dengan menggunakan banten yang digagas oleh Maha Rsi Markandeya kemudian dikembangkan oleh Maha Rsi yang lain seperti; Sangkul Putih, Mpu Kuturan, Mpu Jiwaya, Manik Angkeran dan Mpu Nirartha. Hingga saat ini banten menjadi sarana yang paling penting dalam setiap pelaksanaan ritual upacara. Ketika banten disusun sedemikian rupa, menjadilah sebuah 'candi banten' sekaligus sebagai sebuah persembahan. Candi banten adalah tempat mensthanakan Tuhan Yang Maha Suci, sehingga banten benar-benar harus dijaga kesuciannya. Bahan-bahan terpilih tidak saja bersih tetapi juga sukla (suci), demikian halnya dengan proses pembuatannya.

Umat Hindu khususnya kaum perempuan dalam mempraktekkan pembuatan banten untuk persembahan sesungguhnya telah menerapkan ajaran Yoga melalui pemusatan pikiran. Banten yang dibuat tidak saja merupakan proses kreatifitas dan estetika tetapi juga merupakan proses Yoga karena lebih mengutamakan nilai-nilai kesucian. Pemusatan pikiran terjadi pada saat kaum perempuan menggerakkan jari jemari bagaikan sedang berjapa. Para tukang banten dan 'wiku tapini' dengan posisi bajra asana atau padma asana demi memusatkan pikiran kepada Yang Maha Suci melakukan aktivitas penuh makna kesucian.

Dalam melaksanakan ajaran agama, empat cara/jalan (marga) telah dilaksanakan oleh umat Hindu yaitu; Bhakti marga, Karma marga, Jnana marga dan Raja marga. Bhakti marga dan Karma marga dilaksanakan sebagai tahapan pertama yang biasa disebut 'Apara bhakti' sedangkan tahap berikutnya sesuai dengan kemampuan nalar masing-masing yakni Jnana marga dan Raja marga yang biasa disebut 'Para bhakti'. Pada tahap 'apara bhakti' pemujaan dilaksanakan dengan menggunakan alat-alat bantu seperti banten, simbol-simbol, dan jenis upakara lain, sedangkan pada tahap 'para bhakti' penggunaan banten dan simbol-simbol berkurang (Ngurah, 1999).

Umumnya di Bali keempat marga itu dilaksanakan sekaligus dalam bentuk upacara Agama dengan menggunakan sarana banten yang terdiri dari bahan pokok seperti; daun, bunga, buah, air, dan api. Sarana tersebut memiliki fungsi sebagai: (1) persembahan atau tanda terima kasih kepada Tuhan (Sang Hyang Widhi Wasa); (2) alat konsentrasi memuja Hyang Widhi; (3) simbol Hyang Widhi atau manifestasi-Nya; (4) alat penyucian lahir dan bathin buwana agung dan buwana alit; (5) pengganti mantra (Wiana, 2000). Demikian sakralnya makna banten maka dalam lontar Yadnya Prakerti disebutkan bahwa mereka yang membuat banten hendaknya dapat berkonsentrasi kepada siapa banten itu dihaturkan/dipersembahkan.

Demikianlah pada akhirnya banten menjadi alat bantu dalam pemujaan. Hal inilah yang menyebabkan istilah 'Bali' atau 'Banten' disebut niyasa karena merupakan simbol keagamaan. Hari-hari baik untuk membuat banten juga telah 
ditentukan dengan teliti menurut pawukon oleh para Sulinggih. Pujastuti pareresik banten juga diucapkan melalui doa agar banten tidak dicemari oleh hewan-hewan liar, anak-anak, dan orang yang cuntaka (Gautama, 2011). Bahkan beberapa jenis banten hanya boleh dibuat oleh Sang Dwijati seperti; banten catur, banten pengenteg gumi, dan lainnya.

Untuk menegaskan penting dan sakralnya banten, Mpu Jiwaya di abad ke-10 telah mengajarkan membuat reringgitan dengan bahan daun kelapa, enau, atau daun lontar. Sulitnya membuat reringgitan sehingga memerlukan konsentrasi penuh dan jika tidak maka yang membuat bisa celaka terutama karena tangannya terkena pisau dan reringgitannya menjadi rusak. Bisa dicontohkan bahwa banten yang disiapkan untuk upacara besar di Besakih tempatnya dibuat khusus pada balai (panggung) 'pasucian' tidak boleh dimasuki sembarang orang atau yang tidak berkepentingan. Oleh karena itu, membuat banten harus dalam situasi yang hening, sakral, rasa kasih, tulus-ikhlas, dan terutama karena rasa bhakti terhadap Ida Sanghyang Widhi sebagai implementasi ajaran 'bhakti marga'.

\subsection{Wacana Komersialisasi "Banten" Peluang dan Rejeki Bagi Orang Bali}

Sebagaimana wacana yang telah disebutkan dalam paparan sebelumnya bahwa Bali identik dengan banten. Hal itu memang benar bahwa tidak ada ritual keagamaan orang Hindu-Bali yang tidak menggunakan banten. Ketaqwaan orang Bali sehari-hari diungkapkan dengan sesaji yang diberi nama banten. Karena itu banten merupakan bahasa religius bagi orang Bali (Anom Paketan, 2012). Dalam berbagai teks-teks tradisional kata 'Pulau Bali' dinyatakan dengan sebutan Gumi Banten, karena kata Bali dimaknai sama dengan kata Banten. Jadi banten bukan sekadar ciri atau simbol tetapi juga merupakan jiwa atau roh Bali.

Banten sejatinya persembahan yang diambil dari seisi alam seperti dari tumbuh-tumbuhan dan beragam jenis satwa. Para penekun spiritual di bidang agama menafsirkan banten sebagai cerminan keikhlasan dan rasa terima kasih masyarakat Hindu kehadapan Sang Pencipta. Ketika Hyang Kuasa menganugrahkan limpahan karunia kepada umat manusia, saatnya manusia juga membalasnya dengan persembahan. Apa yang didapat dari alam, itu pula yang dipersembahkan kembali kepada Tuhan dalam wujud banten. Demikian kuat dan pentingnya kehadiran banten dalam kehidupan masyarakat Hindu di Bali menyebabkan kebutuhan masyarakat Bali untuk keperluan sesaji sangat tinggi.

Nilai ekonomi banten di Bali dalam setahun bisa mencapai \pm Rp. 2,8 trilyun. Demikian pula Badan Pusat Statistik Provinsi Bali pernah menyatakan bahwa pengeluaran untuk upacara adat di Bali termasuk kedua setelah konsumsi untuk perumahan. Berdasarkan survei BPS di 120 desa, prosentase pengeluaran upacara adat di perkotaan naik dari 9,95 ? pada Maret 2011 menjadi 12,11 ? pada September 2014. Demikian seterusnya dari tahun ke tahun terus mengalami kenaikan, sementara di pedesaan rata-rata 12 ? pada bulan yang sama (Bali Post, 2015). Kondisi demikian menyebabkan sejak lama telah menggelinding wacana para cerdik cendekiawan Bali untuk menyederhanakan ritual keagamaan Hindu di Bali. Namun hingga saat ini wacana tersebut tetap menjadi bahan perdebatan (kontroversial), karena kesederhanaan yang dimaksud hanya pada taraf tingkatannya saja.

Oleh karena itu, tidak mudah hanya dengan sekadar himbauan belaka karena banyak faktor yang menjadi kendala dan tantangannya. Faktor intern misalnya, bagaimana mungkin masyarakat dapat menyederhanakan ritual jika pada saat menjelang hari raya, harga canang sari mencapai Rp 1000,- per biji dengan alasan harga bunga mahal (terkesan terjadi permainan pasar). Apabila kita menggunakan hitunghitungan ekonomi, kondisi tersebut jelas tidak pernah mencapai balance bahkan membuat kebangkrutan. Namun saking kuatnya keyakinan masyarakat tentang keikhlasan melaksanakan ritual akhirnya dibeli juga, karena mereka memiliki keyakinan dengan tetap menghaturkan sekadar canang, seberapapun biaya yang dihabiskan akan kembali lagi. Sedangkan faktor ekstern yang menjadi kendala dalam melaksanakan ritual lebih sederhana, biasanya ada pada aturan-aturan baku desa pakraman yang mengikat masyarakat menghaturkan sesaji yang jor-joran demi konsumsi pariwisata. Bagi masyarakat yang mampu dan memiliki uang tidak ada masalah, inti pokok ritual yang ada dalam sastra tidak berlaku, tetapi bagi yang 
tidak mampu tetap akan menjadi beban sampai ritual berakhir bahkan sampai ditanggung anak cucunya.

Dengan demikian, upacara keagamaan terutama banten di Bali sesungguhnya dapat menjadi peluang ekonomi bagi masyarakat, bahkan dengan banten dapat menjadikan Bali mandiri secara ekonomi. Ini karena biaya yang dikeluarkan untuk banten pada akhirnya kembali dinikmati masyarakat Bali, seperti; tukang dan dagang banten, petani serta peternak (Sarad,2009). Sementara banyak terlihat di perkotaan peluang yang nyata itu sering diabaikan justru oleh masyarakat Bali sendiri misalnya; berbagai sarana banten tidak lagi berasal dari tanah Bali, pedagang canang sari banyak yang bukan orang Bali. Separuh lebih bahan-bahan banten didatangkan dari luar Bali seperti Jawa, Sulawesi, dan Lombok (Bali Post, Ed.179. 3-9 April 2017). Penyebabnya tidak banyak lagi ada tegalan dan sawah yang bisa ditanami bahan-bahan untuk banten. Begitu para petani semakin menyusut, karena banyak yang beralih mata pencaharian menjadi guide (pemandu wisata) dan pelayan restaurant atau hotel, peluang pasar pun diambil alih oleh masyarakat luar Bali.

Jika dibandingkan dengan dahulu, ketika kehidupan masyarakat Bali sepenuhnya agraris, banten utuh menjadi cerminan keikhlasan manusia Bali. Segala isi banten dari kebun dan sawah sendiri, dikerjakan dengan keringat sendiri, hanya sebagian kecil yang dibeli, terutama bahan-bahan yang tidak tersedia di kebun dan sawahnya. Namun kini, ketika sektor pariwisata berkembang pesat makin jarang terdengar membuat banten bahannya dari hasil kebun atau sawah sendiri. Orang Bali kini sudah umum membeli banten dari pasar atau dari tukang dan dagang banten. Mereka yang melakukan upacara hanya menyiapkan uang secukupnya, banten apapun ada di pasaran, sang pemilik hajatan tinggal menjalankan prosesinya bahkan ada yang terima beres tinggal menghaturkan sembah dan berdoa.

Bali tidak semata tergantung pasokan listrik dari Jawa, tetapi bahan upacara tidak bisa mengabaikan Jawa dan Lombok. Sering terjadi harga-harga berbagai kebutuhan upacara melonjak tajam saat datangnya hari raya. Hal ini disebabkan bukan karena permintaan yang tinggi dari kalangan orang Bali sendiri, namun tidak jarang karena pasokan dari Jawa dan Lombok atau luar Bali terganggu akibat bencana alam banjir, gunung meletus dan terjadilah permainan pasar (Bali Post, 2014). Bagi yang merindukan kemandirian ekonomi Bali tidak pernah lelah mengingatkan agar Bali kembali pada kesahajaan sektor pertanian untuk memenuhi kebutuhan upacara masyarakat Hindu di Bali. Namun, masyarakat Bali terlanjur memandang rendah pilihan hidup bercocok tanam dan beternak. Di samping citra kemiskinan yang begitu lekat terhadap profesi petani, juga karena kehidupan bertani di Bali sudah tidak bisa diandalkan yang membuat anak-anak Bali tidak lagi mimpi menjadi petani.

Beginilah ironisnya ekonomi Bali, di satu sisi perekonomian didorong oleh konsumsi untuk kebutuhan upacara, di sisi lain petani yang seharusnya menjadi sumber kebutuhan bahan upacara terpuruk nasibnya akibat lahannya telah beralih fungsi sehingga hasil yang diperoleh tidak sebanding dengan biaya pengeluaran untuk perawatan kebun atau sawahnya. Walaupun kondisi para petani sudah memperihatinkan namun 'banten' tetap dibutuhkan. Oleh karena itu, agar jangan sampai peluang diambil alih masyarakat pendatang maka perlu pemikiran-pemikiran yang kreatif dalam sistem bertani dan berkebun pada lahan yang sempit sehingga tidak terlalu banyak yang harus dibeli.

\section{PENUTUP}

Sarana upacara yang dinamakan banten sejak abad ke-8 telah dirintis oleh Maha Rsi Markandeya dilanjutkan oleh Maha Rsi lainnya merupakan hal yang mutlak ada karena tertuang dalam ajaran tri kerangka agama Hindu ketiga tentang ritual. Sarana pokok membuat banten juga harus ada. Mengingat zaman telah berganti sampai akhirnya memasuki era digital masyarakat Hindu akan tetap membuat dan menghaturkan banten. Namun, dalam hal ini perlu lebih menekankan kesederhanaan bahwa membuat dan menghaturkan banten dapat menyesuaikan dengan situasi, kondisi, dan kemampuan (desa, kala patra) masing-masing umat. Ada banten alit tidak berarti nilainya lebih rendah dari banten madya dan utama demikian sebaliknya. Selain faktor situasi dan kondisi, tetandingan 'banten' juga dapat disederhanakan 
misalnya; banten yang biasanya menggunakan lima nampan dijadikan satu nampan saja. Hal ini menunjukkan kuatnya ciri identitas kehinduan masyarakat di Bali agar tetap dapat mempertahankan 'banten'. Dengan demikian membuat banten tidak perlu membebani umat yang hendak menunjukkan bhaktinya kehadapan Tuhan.

Kehadiran banten dalam tradisi di Bali mencerminkan kuatnya identitas kehinduan atas keyakinan masyarakat kepada Sang Pencipta. Ideologi tersebut melekat turuntemurun sehingga menjadi warisan leluhur. Dengan memahami hakikat banten sebagai curahan rasa bhakti dan cinta kasih kepada Sang Pencipta banten hendaknya dihaturkan dengan penuh keikhlasan. Persembahan umat Hindu dengan perasaan tulus dan ikhlas telah mengimplementasikan ajaran bhakti marga. Dari keempat marga/cara yang dikenal dengan catur marga, untuk mendekatkan diri kehadapan Tuhan semuanya menggunakan sarana banten. Namun demikian, penggunaan banten lebih banyak pada tahap 'apara bhakti' sebagai dasar dalam menjalankan bhakti marga dan karma marga. Sedangkan tahap 'para bhakti' dasar ajaran jnana dan raja marga penggunaan banten dikurangi. Dengan demikian masyarakat Hindu di Bali tidak dapat dipisahkan dari banten walau sedang dalam kondisi krisis sekali pun karena banten merupakan implementasi dari ajaran bhakti marga.

Dalam kenyataannya, tidak semua umat Hindu bisa dan biasa membuat banten terutama di perkotaan dimana satu keluarga sibuk bekerja mencari nafkah, dengan waktu yang terbatas, muncul keinginan serba praktis/ekonomis, disamping langkanya bahan baku banten. Maka dalam kondisi seperti itulah banten pun dapat diperjual belikan (dikomersialkan) di pasaran. Kefleksibelan dan keluwesan dalam penerapan ajaran bhakti marga memaklumi bahkan tidak menyalahkan umatnya, asalkan banten yang dipersembahkan tetap menunjukkan kesakralan, keikhlasan dan kesuciannya. 'Banten' memang memendam potensi ekonomi luar biasa bagi masyarakat Bali karena banten tidak pernah lekang oleh zaman. Selama banten masih menjadi kebutuhan primer masyarakat Bali selama itu pula potensi ekonomi banten tetap hidup. Bahkan banten tidak pernah terpengaruh iklim/cuaca, jangankan saat situasi ekonomi bagus, ketika situasi ekonomi sedang sulit misalnya, terjadi musibah pun banten tetap dibutuhkan demi ajegnya tradisi leluhur yang telah diwariskan secara turun-temurun.

\section{DAFTAR PUSTAKA}

Bhaktivedanta, Swami Prabhupada, Sri Srimad A.C. tt. Bhagavad-Gita Menurut Aslinya. Penerbit: The Bhaktivedanta Book Trust.

Budha Gautama, Wayan. 2011. Rerahinan. Hari-Hari Raya Umat Beragama Hindu. Gianyar: Penerbit Gandapura.

Mas Putra, I Gusti Agung. 1974. “Upakara Yadnya”. Denpasar: Institut Hindu Dharma.

Ngurah, I Gusti Made, dkk. 1999. Pendidikan Agama Hindu Untuk Perguruan Tinggi. Surabaya: Penerbit Paramita.

Panitia Penyusun. 1978. Kamus Bali-Indonesia. Denpasar: Dinas Pengajaran Propinsi Daerah Tingkat I Bali.

Paramita, I Gusti Agung. 2018. Bencana, Agama dan Kearifan Lokal. (Jurnal Dharmasmrti Vol. 1 No. 18, Denpasar Jurnal Ilmu Agama dan Kebudayaan Universitas Hindu Indonesia, 2018).

Paketan, Ida Bagus Anom. 2012. Ista Dewata dan Rerahinan Agama Hindu. Denpasar: CV. Kayu Mas Agung.

Singer, I Wayan. 2014. Kekuatan Yajña. Surabaya: Penerbit Paramita.

Wiana, I Ketut. 2000. Arti dan Fungsi Sarana Persembahyangan. Surabaya: Penerbit Paramita.

Lontar: Yajña Prakerti. Koleksi PGA Hindu Negeri Denpasar.

Lontar: Kusuma Dewa. Koleksi Perpustakaan IHD Denpasar.

Koran dan Majalah Bali Post, (2014 dan 2017)

Majalah Sarad, (2009) 